\title{
Master Plan as A Tool for Post-Mining Water Reservoirs Management - A Cases in Poland
}

\author{
Joanna Kulczycka $^{1, *}$, Elżbieta Pietrzyk-Sokulska ${ }^{2}$ \\ ${ }^{1}$ Faculty of Management, AGH University of Science and Technology, Krakow, Poland \\ ${ }^{2}$ Mineral and Energy Economy Research Institute of the Polish Academy of Sciences, Krakow, Poland \\ *Corresponding author: kulczycka@meeri.pl
}

Received July 19, 2013; Revised July 31, 2013; Accepted August 01, 2013

\begin{abstract}
Master plan can be a valuable tool used in planning process. Although there are no regulations in Poland on the development of master plans, it can play important role both for strategic, sector, local or urban planning projects. There is also called environmental master plan when it focus on solving individual environmental problems. Generally, master plan allow data to be collected, identify the baseline scenario and set targets against it, estimate the effects of plans and finally to utilize information for public consultancy and for financial planning. The scope of environmental master plan for two different (polluted and not-polluted) post-mining reservoirs, .i.e. Górka and Balaton, located nearby are presented. The main aim of this master plan was to find optimal solution, which can maintain good water quality in Balaton reservoir, through minimization of environmental hazards in Górka reservoir. Therefore in master plan current legal, environmental, technical, spatial, social and financial issues were analysed to indicate potential beneficiaries and treats. The results of these analysis were presented using SWOT methods. As it was complex study SWOT was created first for external factors and next for internal. It was found that such complex SWOT was useful for communication with local society and in decision making process. The proposed solution can be a benchmark for other similar objects, as it takes into account all important aspects as a basis for the selection of the strategic goal of increasing water resources and the maintenance of good quality water in the region.
\end{abstract}

Keywords: post-mining reservoir, reclamation, masterplan, SWOT

Cite This Article: Kulczycka Joanna, and Elżbieta Pietrzyk-Sokulska, "Master Plan as A Tool for PostMining Water Reservoirs Management - A Cases in Poland." American Journal of Environmental Protection 1, no. 3 (2013): 59-65. doi: 10.12691/env-1-3-3.

\section{Introduction}

In Europe one third of the population lives in areas with severe pressure on water resources, therefore identification and promotion of methods to improve the quality and quantity of water resources being in line with the principles of sustainable development is urgent subject. This will involve both the maintenance of existing surface water resources and increasing the retention and restoration of current water systems. Master plan can be a valuable tool for sustainable water resources planning. Although there are no regulations on the development of master plans in Poland, it can play important role both for:

- large strategic projects for sectors [2],

- regional planning projects [7],

- urban planning [3],

- individual object planning, i.e. environmental master plans which focus on solving individual environmental problems [1,5].

Generally, master plans allow data to be collected, identify the baseline scenario and set targets against it, estimate the effects of plans and finally to utilize information for public consultancy and for financial planning. Through an in-depth analysis of all existing conditions and an assessment of future needs, it facilitates the implementation of the new "optimal" solutions.

The final solution for two post-mining water reservoirs management called Górka and Balaton based on prepared environmental master plan is presented in the paper. It can be a benchmark for other similar objects, as it takes into account all technical, legal, environmental, spatial, economic, social aspects as a basis for the selection of the strategic goal of increasing water resources and the maintenance of good quality water in the region.

\section{Characteristics of the Selected Areas for Analysis}

Two post-mining reservoirs located in the south part of Poland were analysed. The first known as Lake Balaton is a remnant of an old limestone quarry which ceased production in the 1970s, and is currently used as a swimming area. After the cessation of pumping, rainwater and groundwater formed in the bowl of the quarry covering an area of 3 hectares. The water level stabilized at 12 meters (max. depth) to match the surrounding walls of the old workings (Figure 1).

Following the flooding, and due to the transparency of the water (Figure 2) and good oxygenation levels, conditions 
are favorable for the development of different types of fish (such as carp, pike, perch, trout). This makes the area attractive for both fishing and diving.

The Lake Balaton is not fully managed as it is located nearby an “ecological bomb” called Górka. Górka is notmanaged for over 30 years abandon quarry filled with 600,000 tonnes of red mud waste which is washed with rainwater and groundwater from the headwaters. As a result, a leachate pit has filled with water of a high $\mathrm{pH}$ (> 13) and high concentrations of other hazardous compounds (Figure 3).

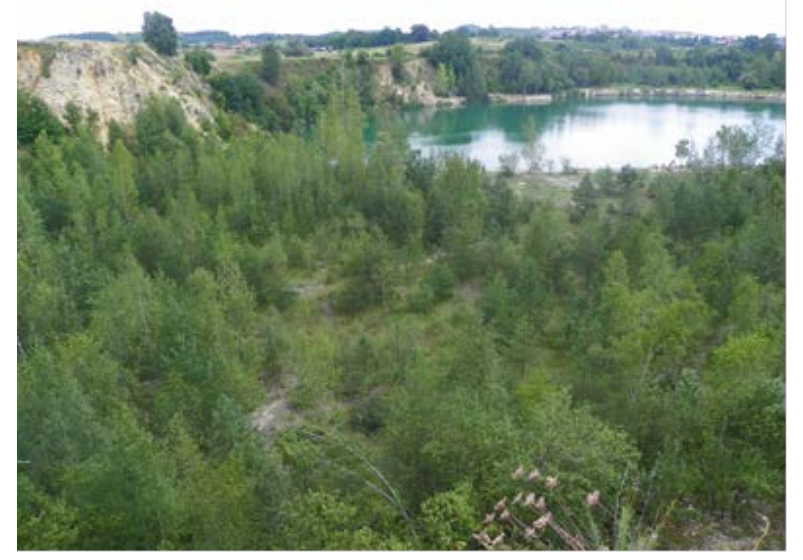

Figure 1. View of the bay Balaton. Photo: L. Lelek

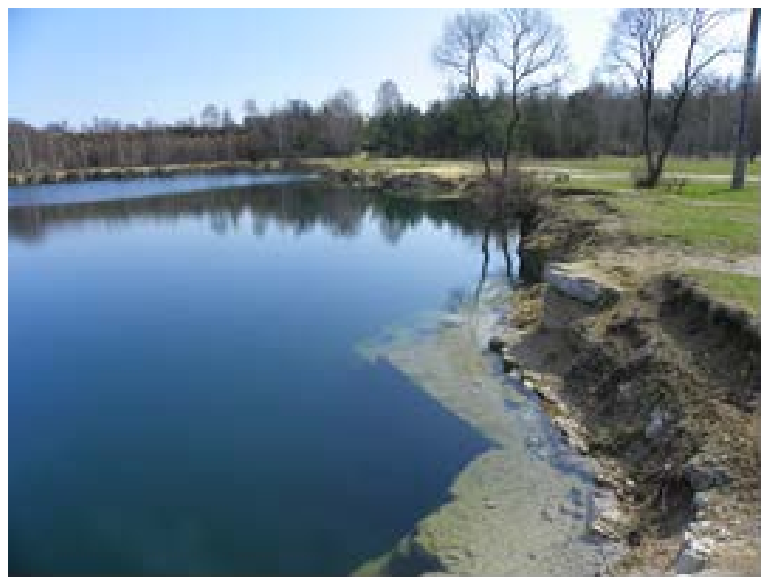

Figure 2. Balaton reservoir water. Photo: E. Pietrzyk-Sokulska

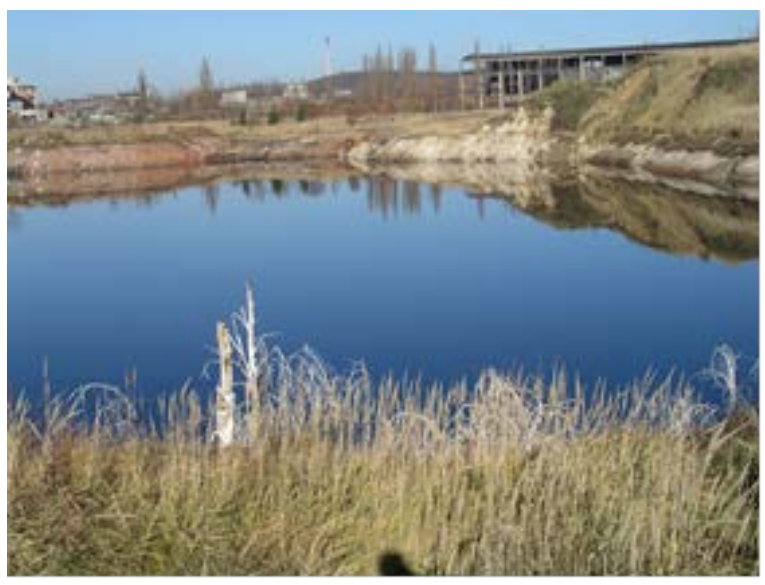

Figure 3. Alkaline leachate in the Górka hollow (2006). Photo. E. Pietrzyk-Sokulska
This red mud is mostly solid waste from the nearby production of alumina using the Bayer process, and consisting of silica $\left(\mathrm{SiO}_{2}\right)$, simple silicates and aluminosilicates of calcium and aluminum and iron oxides. These wastes have previously been mixed with the waste from the production of cement and fireproofing materials and construction debris, scrap, municipal waste and possibly sediment from sewage treatment plants. The waste has been stored by company which bankrupted about 30 years ago, and the area have not been reclaimed. The municipality (local government) started to supervise this area but has not sufficient funds for it complex reclamation and management, therefore they decide to discharged excess leachate by gravity into an existing tunnel, which leads to the nearby wastewater treatment plant. In 2000 the drainage tunnel silted up and became ineffective, resulting in leachate accumulation at the edge of the pit which threatened to overflow and potentially contaminate the surrounding land. The municipality also undertook repairs to the water basin to reduce the risk of spillage and leachate contamination in the surrounding area. This required pumping and neutralisation of the alkaline leachate and removal of the silt from the adit to drain leachate safely by gravity to a local stream. The cost of these treatments was in excess of 10 million USD, and was met by the budgets of the municipality. The water pit still accumulated leachate, which is monitored by the commune office, who as landowners are directly interested in maintaining the safety of the area.

It is worth noting that this area is characterized by adverse geological conditions with multiple fractures, karst, and other features which facilitate the infiltration of leachate potentially close to the Central Groundwater Basin (GZWP 452-Chrzanów), which supplies the district with water for drinking. For this reason the pit is covered by the highest level of protection (known as ONO). The walls surrounding the reservoir have different heights (from 4-15 m) and slopes of 60-70o. As a result of prolonged immersion in alkaline liquids they are currently unstable, saturated with water, which has led to many landslides. There are places on the slopes where the different levels of leachate impoundment in the reservoir are visible. This creates a potential threat of leachate infiltration deep into the rock and because the Górka Adit is located above the recreational pool at Balaton, this poses a further threat to the water quality in the Balaton lagoon.

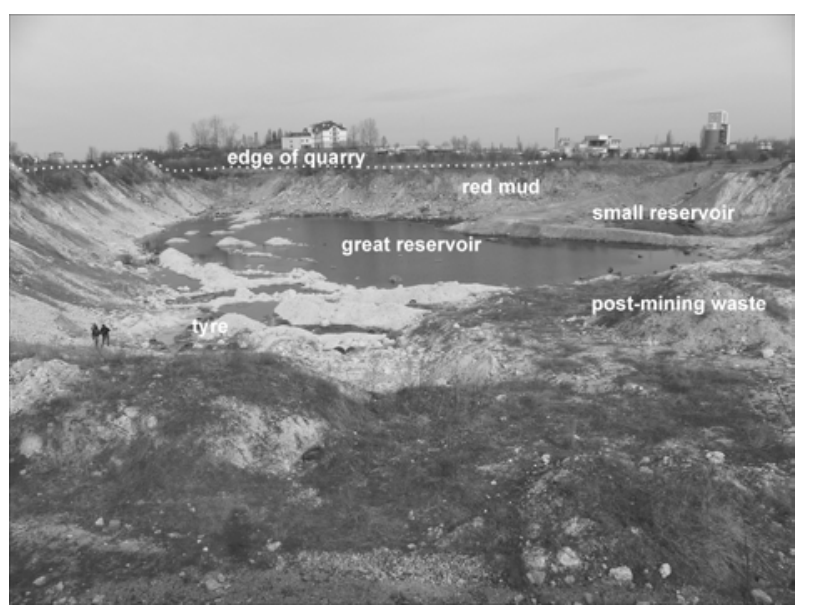

Figure 4. Reservoir Górka - current view. Photo: L. Lelek 
Currently, the reservoir Górka, after intensive pumping of leachate in recent years, consists of two tanks - one big and one small, separated by a waste dump which acts as a dam. They have a depth of $30 \mathrm{~cm}$ to $1 \mathrm{~m}$, which is largely dependent on the intensity of rainfall and the inflow of water from the headwaters area, located to the eastern side of the reservoir (Figure 4).

Draining the more hazardous leachate minimises the risk, but only a comprehensive rehabilitation (technical and biological) and the development of the area will eliminate them completely, and enable the restoration of the area's utility and recreational potential. The degraded site will recover its natural valors and utility value in 2013-2015 thanks to the support of national and EU funds.

Minimization of hazards in reservoir Górka, and to maintain good water quality in Balaton Lake requires a comprehensive approach that will allow safe use by the inhabitants of Trzebinia and visitors. The operational priorities are:

- eliminate hazards in Górka - drained alkaline leachate,

- protection of headwaters,

- land reclamation of industrial waste "red mud",

- provide funding for safety work,

- improve environmental quality standards,

- increase attractiveness of the site,

- adaptation of water bodies surrounding recreational areas,

- provide access to the nearby residents,

- creation of public-private partnership (PPP) for the use of brownfield sites,

- increase the competitiveness of the municipality.

The priorities for action under the specific needs of the community must be balanced with the preservation of the environment. To safeguard the environment these are:

- ordering the excavation of the existing Górka (technical and biological reclamation),

- protection of headwater sites from pollution from the landfill leachate red mud,
- elimination of sludge from the bottom of the Górka quarry,

- development of the Balaton reservoir environment (implementation of the architectural concept of the Ecological Park)

- supervision of newly created features.

The implementation of the actions outlined in the master plan will ultimately:

- improve the image of the municipality (brownfield liquidation, recovery areas for redevelopment, the protection of areas of high natural value against buildings and industrialization, increase quality of life for residents);

- eliminate the possibility of an environmental disaster (especially surface water and soil),

- increase the attractiveness of the community and its ability to compete with neighboring communities for potential investors (recreational functions),

- economic benefits - job creation mainly in the service sector and from the use of revitalized areas

- further development of the municipality.

\section{Master Plan as a Tool for Sustainable Water Management}

The master plan takes into account current legal, environmental, spatial, social, technical and financial issues and indicate potential beneficiaries and treats to find the optimal solution for established aim, i.e. to improve the quality of water in Balaton Lake and minimisation of hazards in Górka. First SWOT analysis was used to assess the external factors - all aspects concerning the analysed aspects, which could have impact on possible reclamations and management of the Górka and Balaton reservoirs. Strenght and weakness were analysed for seven different areas i.e.: geographical location and communication, resources and cultural heritage, environment, demography and social aspects, economy, infrastructure, administration (Table 1).

Table 1. SWOT analysis for reclamation of Górka and Balaton reservoirs - assessment of external factors

\begin{tabular}{|c|c|}
\hline STRENGTHS & WEAKNESSES \\
\hline \multicolumn{2}{|c|}{ Geographical location and communication } \\
\hline $\begin{array}{l}\text { - Geographical location between the economically developed regions - Silesia and } \\
\text { - Malopolska; } \\
\text { - Improved communication links: } \\
\text { - Traffic: A4 motorway, } \\
\text { - Krakow-Katowice and provincial Trzebinia Olkusz } \\
\text { - railway junction - Trzebinia; } \\
\text { - LHS bus and Sławków Bukowno; } \\
\text { - International Airport - Balice and Pyrzowice; }\end{array}$ & $\begin{array}{l}\text { - No bypass road around Trzebinia; } \\
\text { - Poor condition of roads; } \\
\text { - inconvenient transportation system within the municipality; } \\
\text { - No designated road lanes for cyclists. }\end{array}$ \\
\hline \multicolumn{2}{|l|}{$\begin{array}{ll} & \text { Resources and cultural heritage }\end{array}$} \\
\hline $\begin{array}{l}\text { - documented rock mineral deposits; } \\
\text { - MGB - } 452 \text { Chrzanów, } 453 \text { Bishops Bor, } 454 \text { Olkusz Zawiercie, } 457 \text { Tychy } \\
\text { Siersza; } \\
\text { - The fertile and unpolluted soil in E part of the municipality; } \\
\text { - A large area of forests, including fragments of natural forests (Dulowska); } \\
\text { - Diversity of terrain; } \\
\text { - Protected areas (PK Cracow Valleys; reserves); } \\
\text { - Unique geological profiles (necrosis karniowicka, conglomerates } \\
\text { - } \text { myslachowickie); } \\
\text { - landscape and cultural values (palaces and mansions with parks); } \\
\text { - educational paths and geological sciences; } \\
\text { - Monuments Judaica (Jewish cemeteries, synagogues); } \\
\text { - Tourism pilgrimage (Płoki, Trzebinia) }\end{array}$ & $\begin{array}{l}\text { - Exhausted mineral deposits (coal and ore } \mathrm{Zn}-\mathrm{Pb} \text { ); } \\
\text { - Low agricultural land use; } \\
\text { - An environmental hazard of dust and gas industry; } \\
\text { - A large area of degraded land; } \\
\text { - Lack of protection and conservation of historic mining sites; } \\
\text { - Poorly developed tourist industry }\end{array}$ \\
\hline
\end{tabular}




\begin{tabular}{|c|c|}
\hline \multicolumn{2}{|l|}{ Environment } \\
\hline $\begin{array}{l}\text { - Implemented EMAS } \\
\text { - Environmental Statements; } \\
\text { - Removal of noxious industrial plants; } \\
\text { - Revitalization of the historic part of the city Trzebinia (market); } \\
\text { - pro-environmental activities (reclamation of Górka) }\end{array}$ & $\begin{array}{l}\text { - Degraded industrial areas - fragmentation; } \\
\text { - Wild landfills and fly tipping; } \\
\text { - Contaminated surface water; } \\
\text { - Emissions from small point sources; } \\
\text { - Risk of groundwater quality related to the decommissioning } \\
\text { of underground mines; } \\
\text { - lack of funding for improvement of the environment; } \\
\text { - neglected historic buildings }\end{array}$ \\
\hline \multicolumn{2}{|c|}{ Demographic and social aspetcs } \\
\hline $\begin{array}{l}\text { - well-educated managers; } \\
\text { - proximity to research centers (Cracow, Katowice, Gliwice); } \\
\text { - adapting the educational offer to the current needs of the labor market; } \\
\text { - social activity and strong links with the community; } \\
\text { - Good communication with local residents (website of the Office); } \\
\text { - NGOs; } \\
\text { - partnership Polish and EU regions }\end{array}$ & $\begin{array}{l}\text { - elimination of the leading factories - loss of jobs; } \\
\text { - migration of young people (for work); } \\
\text { - impoverished communities; } \\
\text { - threat to the development of social pathology; } \\
\text { - an aging population; } \\
\text { - Lack of extracurricular activities for young people; }\end{array}$ \\
\hline \multicolumn{2}{|l|}{$\begin{array}{ll}2 & 200 m y \\
\end{array}$} \\
\hline $\begin{array}{l}\text { - Large industrial center - mining, refining, energy; } \\
\text { - free municipal land for development; } \\
\text { - concepts of economic zones in industrial areas; } \\
\text { - new technologies to eliminate the threat to the environment; } \\
\text { - assistance programs for entrepreneurs; } \\
\text { - community-friendly investors - tax breaks, etc. }\end{array}$ & $\begin{array}{l}\text { - the image of the municipality after the restructuring of the } \\
\text { - industry; } \\
\text { - degraded soil - heavy metal contamination; } \\
\text { - disappearance of agriculture - set-aside; } \\
\text { - fragmentation of agricultural holdings; } \\
\text { - No part of the local development plan for the municipality - } \\
\text { difficulties in the implementation of investment }\end{array}$ \\
\hline \multicolumn{2}{|r|}{ 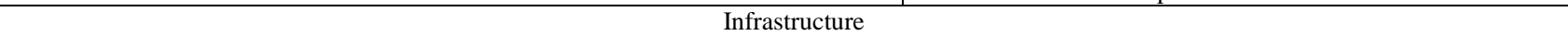 } \\
\hline $\begin{array}{l}\text { - well-developed municipal infrastructure, power grid, telecommunications in } \\
\text { Trzebinia; } \\
\text { - landfill for municipal waste; }\end{array}$ & $\begin{array}{l}\text { - villages and rural communities have limited sewerage } \\
\text { connections; } \\
\text { - Lack of fully prepared land for housing development; } \\
\text { - limited landfill capacity; }\end{array}$ \\
\hline \multicolumn{2}{|l|}{ Administration } \\
\hline $\begin{array}{l}\text { - a significant role in the creation of local community development; } \\
\text { - implementation of ISO 9001; } \\
\text { - cooperation with EU partners and other regions }\end{array}$ & • self-loading new tasks without adequate financial resources \\
\hline OPPORTUNITIES & THREATS \\
\hline $\begin{array}{l}\text { - The economic growth of the country; } \\
\text { - Development of small and medium-sized enterprises; } \\
\text { - financial support from the EU, especially for investment and infrastructure } \\
\text { - development; } \\
\text { - Ability to use financial support } \\
\text { - The EU regeneration investment; } \\
\text { - Improving international political and economic climate; } \\
\text { - the interest of foreign investors; } \\
\text { - Relatively cheap labor; } \\
\text { - } \text { Ability to use proximity and potential of large urban areas; } \\
\text { - The development of the tourism market in Poland, } \\
\text { - Tourism industry; } \\
\text { - External financing of projects in the field of environmental protection (protection } \\
\text { funds Environment, Eco-Fund); } \\
\text { - The development of alternative, non-agricultural sources } \\
\text { - maintenance of the rural population (including agro-and geotourism); } \\
\text { - Work with neighboring communities to improve communication and public } \\
\text { - The efficient functioning of the capital market; } \\
\text { - The functioning business environment. }\end{array}$ & $\begin{array}{l}\text { - Variable political situation in Poland and in the world - the } \\
\text { global crisis; } \\
\text { - Frequent change of legislation - the brake on SME } \\
\text { development and economic activity; } \\
\text { - Complicated and long-standing procedure for access to EU } \\
\text { funds; } \\
\text { - Increasing competition in neighboring regions; } \\
\text { - An increase in the tax burden on the population; } \\
\text { - The outflow of population and capital to the EU; } \\
\text { - Low purchasing power of the public }\end{array}$ \\
\hline
\end{tabular}

\section{Source: [4]}

Than SWOT was proposed for internal factors, i.e. all aspect connected with reclamation of Górka and Balaton reservoir, but strenght, weakness, opportunities and threats were analysed for four different areas i.e.: the image and community perception, spatial and functional structure, environment, economic development aspects (Table 2).

The SWOT analysis suggests that the possible risks and weaknesses relate primarily to financial and environmental issues. It is important that the further development tackles the potential contamination of the site associated with the industrialisation of the region and the changes resulting from the flooding of mines. Although there is no direct competition for the development of water tourism, the surrounding areas have a high quality natural and cultural environment, and have already developed tourist infrastructure based on cultural and other forms of tourism. The recent analysis indicates that a previous cessation of the remediation at Górka lead to the marginalisation of the entire area; it also shows that there may be an opportunity to create a combined recreational and leisure complex with the adjacent Lake Balaton, which would potentially attract large numbers of tourists and increase the prospects for tourism and economic development of the region. This approach will requires suitable master planning to ensure the needs and capacities of the local community and future beneficiaries are taken into consideration. SWOT analysis is of particular importance in the master plan as a reference for the developed plans and takes into account technical, economic, environmental, demographic, spatial, social and 
organizational issues. It is particularly useful for the

as a universal tool for the initial strategic analysis. strategic planning for the country, province or municipality,

Table 2. Analysis for reclamation of Górka and Balaton reservoirs - assessment of internal factors

\begin{tabular}{|l|}
\hline \multicolumn{2}{|c|}{ STRENGTHS } \\
\hline - Diversity of terrain - many geographic regions; \\
- Convenient location at the crossroads of two powerful economic regions: \\
Silesia and Lesser Poland; \\
- Good accessibility: \\
- the road - A4 motorway, provincial road 79, 791 National \\
- the railway - railway junction in Trzebinia \\
- the air - Balice International Airport (20 km), Pyrzowice (about $50 \mathrm{~km}$ ). \\
\hline
\end{tabular}

- Low level of urbanization (mostly rural communities);

- The restructuring of industry harmful to the environment; Spatial and functional structure

- Significant areas fully serviced for new investments;

- Artificial water bodies partially developed for recreation;

- architectural monuments, historical and industrial (mining traditions);

- Numerous shrines - pilgrimages;

- The development of various forms of tourism (cycling, pilgrimage, water, Geotourism);

- Revitalization of urban space Trzebinia;

- Plans for economic zones in selected industrial areas. WEAKNESSES

Environment

- A large area of forest $>40 \%$ (including some fragments of ancient forests);

- protected objects (PK, reserves); munity perception

- significant industrialization;

- numerous brownfield sites;

- disposal of industrial and mining waste

- mining damage (basin subsidence, excavation, flooding).

- Large bio-and geodiversity;

- Groundwater resources of great utility (MGB);

- Current environmental declarations (EMAS for municipalities)

- community development strategies 2007-2015, environmental programs, annual reports on completed projects, etc.

- Large industrial plants; Economic development factors

- A significant indicator of economic activity (SME service-commercial);

- Well-educated workforce;

- Activity at the local, regional, national and international level (municipalities and cities);

- Cooperation with local research centers in Krakow;

- Efficient Web information on the community;

- In-house, local newspaper;

- Many non-governmental organizations;

- A significant relationship with local residents. OPPORTUNITIES

- No bypass Trzebinia (transit traffic);

- Limited recreational facilities, hotels and restaurants;

- No strategy for the development of different forms of tourism in harmony with local values and resources;

- Significant damage to buildings on brownfields - places occupied by the margins of society;

- Spare capacity monuments (palaces, cemeteries and Jewish cultural objects);

- Competitiveness of adjacent areas.

\section{- Poor quality of surface water;}

- The possibility of groundwater contamination.

\begin{tabular}{|c|c|}
\hline OPPORTUNITIES & THREATS \\
\hline \multicolumn{2}{|c|}{ The image and community perception } \\
\hline $\begin{array}{l}\text { - Improving the image of the community, } \\
\text { - Tourist promotion outside of the Municipality, } \\
\text { - New jobs, } \\
\text { - Social acceptance, } \\
\text { - Attempts to develop brownfield sites; } \\
\text { - Support of local authorities; } \\
\text { - foncepts prepared for the reclamation and development of brownfield sites } \\
\text { for complional facilities. }\end{array}$ & $\begin{array}{l}\text { - The high cost of rehabilitation and adaptation projects for } \\
\text { brownfield sites } \\
\text { - Lack of private entities willing to PPP (eg for the development of } \\
\text { brownfield sites); } \\
\text { - maintenance and monitoring of new proposals. }\end{array}$ \\
\hline
\end{tabular}
for complex recreational facilities.

- Upgrading of roads and railways; Spatial and functional structure

- The development of recreational and leisure areas on the basis of existing - Increasing the leve
of former mines.

water bodies and thematic paths,

- The ability to change the main function of the municipality from agroindustrial to tourism;

- The development of geotourism.

Environment

- Solution of contaminated water problems (such as Górka)

- Restoration of attractive sites;

- Protection against re-contamination due to land reclamation,

- Monitoring of water quality in artificial ponds designed for swimming;

- The development of biodiversity by increasing "green" areas.

- Ownership of brownfield sites;

- Limited PPP activity in new ventures (eg industrial areas);

- Low public awareness of people qualities and development possibilities (conflict of interest);

- Promotion of natural assets and certain forms of tourism on the local forum;

- There is no comprehensive vision of the development of different forms of tourism.

- High income in community (65\%);

- The development of local entrepreneurship,

- Inflow of new technologies;

- Functioning business environment;

- Ability to raise funds from the EU and other sources for investment for environmental, recreational and sports facilities.

\section{Economic development aspects}

- Reduction of jobs as a result of industrial restructuring;

- Low rate of men below productive age (17\%);

- Issues of land ownership in the areas of new investment;

- Instability and banking regulations;

- Low commitment to the business lobby and its surroundings in new investments;

- Rapid development of competitive neighboring areas;

- Lack of comprehensive promotion of the community in the region. 


\section{Reclamation Variants at Górka and Balaton Reservoirs}

Various options and subsequent reclamation plans were considered for Górka. The environmental and economic conditions were evaluated and this provided the basis for the selection of the best option. Four different variations were proposed in the planning documents [6]. The main aim of each of the variants was to propose a technical solution at reasonable cost that will effectively eliminate the threat to the environment from the red mud leachate. The scope of work focuses on remediation (technical and biological), in order to return the post-industrial sites to a more natural state. The proposed work covers site remediation, and at the appropriate time, to undertake water quality monitoring. This will observe the vegetation and assess the stability of the landfill area. Based largely on the cost of reclamation and environmental benefits, variant in which the majority of red mud will be encapsulated in-situ while municipal waste debris, tyres, scrap metal and bottom sludges will be removed. An estimated $5,000 \mathrm{~m}^{3}$ of sludge will be dried and taken to a special landfill for hazardous waste within the municipality of Trzebinia. The remaining materials are to be placed in municipal waste, after being isolated from rainwater and groundwater flows. Some industrial waste from the headwaters area is to be moved to the plateau storage, thereby reducing the space they occupy.

The plateau and associated slopes will be formed at the artificially created headwaters gorge, in a specially lined stone tunnel. However, rain water collected in the foothills of the site drainage system will be directed to the tunnel. In this way, waste should be totally isolated from contact with water (rain water and groundwater). The plateau will additionally be sealed with a $1 \mathrm{~m}$ thick layer of bentonite. This will help the rehabilitation of the area which is planned to incorporate around 32,000 shrubs and trees. The species selected will be those most likely to adjust to the environment. The reclamation and regeneration work will be carried out over an area of 11.5 ha.

The advantage of this option is that it can turn the area into a vibrant post-industrial landscape, both in natural and cultural terms. The proposed development will benefit from its location close to the centre of Trzebinia. Being set up in the canopy of the former workings should also help to improve the micro-climate. The depth of the water will be variable depending on the drop (an average of about 2 $\mathrm{m})$. Rushes planted here will create the habitats required to attract certain birds and amphibians, thus creating a secondary habitat. On the top of the old workings, along the edge, it is proposed to place boundary posts, setting out the boundaries by delineating them with a rope. It is also proposed to create an educational path with explanatory plaques with stories relating to the area. The chosen technologies allow for an understanding of risk, but they are different in terms of environmental impact, the use of land and the cost of the work. Capital expenditure is estimated at 24.4 million PLN, with operating costs of 0.1 million PLN per year. Due to the need to carry out wide ranging earthworks and create a new drainage systems, there will be strict construction work requirements in line with construction law.
Implementation of this option would restore the current land values and environmental utility values. The revitalization process (including cleaning, reconstruction and modernisation of the existing land cover) would help to restore the natural environmental functions of the area. This option would also prevent water from flowing through the waste currently associated with the pit of the headwaters area.

\section{Conclusion}

The master plan is a comprehensive assessment tool to solve a problem in the development of infrastructure increasingly being used by local and regional authorities in the EU. Its aim is to propose and choose the optimal solution for the identified problem, such as the improvement of the water environment in the region. Based on an example concerning the water bodies at Górka and Balaton reservoir, which, despite the fact that they are under the management of different levels of government, have been presented as one joint project in a common document. The essence and purpose of the master plan was to search for solutions that allow for the use of synergies arising from the location and mutual dependence of the water bodies, in addition to determining their key functions in the region. The advantage of the master plan approach is that it analyses the problems associated with the water bodies taking into consideration local, regional, national and EU level policies, regulations and funding opportunities. This makes it possible to identify recommendations and proposed changes in these areas.

In terms of improving the local environment it is important to:

1. Increase environmental awareness of residents regarding both the environmental risks and the opportunities for improvement to local quality of life,

2. Intensification of cooperation between local authorities and local entrepreneurs in the development of brownfield sites at Górka and Lake Balaton and their surroundings. This includes the comprehensive rehabilitation and management for recreational purposes, for example, with the help of PPP,

3. Comprehensive use of all the advantages of the surrounding environment Górka and Balaton reservoirs; with the involvement of municipalities, banks, businesses, residents and tourism NGOs this should ultimately lead to the creation of natural paths, the development of geotourism attractions (on the basis of rocks, caves, pits post-mining areas of geological interest) and the renovation and adaptation of historic buildings, including mansions and palaces for purposes such as recreation and training, The creation of a local marketing strategy to attract entrepreneurs to invest in this area, including through the use proposed in the master plan concept of architectural 3D visualization showing the development of tourism infrastructure around the water bodies. This will inform the community on an ongoing basis of favorable investment conditions for industrial areas, and help restore the natural environmental and utility value of the land. This is particularly important 
due to the vicinity of the recently created infrastructure for Economic Activity Zone (2020),

4. Creating effective instruments to support the development of local entrepreneurship for regeneration projects - the search for sources of financing for entrepreneurs interested in investing on tourism and recreational brownfield sites,

5. Development of cooperation between local management entities and recreational facilities, including the exchange of knowledge in the field of management models, the creation of joint promotional and advertising materials, local products, etc.,

6. Implementation of PPP regeneration projects in former industrial areas.

At the regional level it is important to:

1. Take into account the strategies of tourism development possibilities within water based areas, including established mining areas,

2. Develop programs to include small retention reservoirs created in the old quarry.

In terms of national importance there should be:

1. Location mapping of industrial areas in Poland, together with a description of natural conditions around them,

2. Creation of a national strategy for the development of industrial areas, including the potential to develop reservoirs in some former industrial areas,

3. For bathing in established mining areas it appears necessary to ensure there is a ministerial level regulation profile of water at different depths (every four years) to identify potential health-threatening contaminants that can be leached from the sediment,

4. Promotion and support for PPP activities, and the coordination and implementation of tasks to effectively prepare and implement projects. This will include taking action relating to the advice and support of public bodies in the preparation of PPP projects, cooperation with the European Knowledge Centre for the PPP, the European Commission and the European Investment Bank and other national and international institutions including the exchange of best practices,
5. The introduction of legal changes to facilitate development of the "wild" water bodies.

At the EU level there is potential for:

1. Further expansion of cooperation in the framework of EU projects (eg Interreg) for the exchange of best practices and solutions in selected research areas, including water management,

2. Increasing the role of the European Water Information System (WISE),

3. Maintaining financial support for activities related to the increasing use of water resources in the EU and to improve their quality,

4. The introduction of the master plan as a standard for procedures for planning and management of water reservoirs and wetlands in the EU in order to increase water resources and maintain appropriate quality,

5. Development of master planning as a tool for the management of water bodies and wetlands at EU level, together with the creation of uniform guidelines for their design and implementation.

\section{References}

[1] Assaf, H. and Saadeh, M., “Assessing water quality management options in the Upper Litani Basin, Lebanon, using an integrated GIS-based decision support system,” Environmental Modelling \& Software 23. 1327-1337. 2008.

[2] Energy Master Planning (EMP) Tool, SEAI, 2010, [E-book] Available:

http://www.seai.ie/SEC/Toolkit/Energy_Master_Plan_Help_Guide .pdf.

[3] Louw, E., "Land assembly for urban transformation-The case of 's-Hertogenbosch in The Netherlands," Land Use Policy 25. 69-80. 2008.

[4] Pietrzyk-Sokulska, E. and Kulczycka, J., Masterplan for the Górka and Balaton reservoirs, MEERI press, Krakow (Poland). 2013.

[5] Setiawatia, E., Notodarmojob, S., Soewondoc, P., Effendid, A.J. and Otoka, B.W., "Procedia Infrastructure development strategy for sustainable wastewater system by using SEM Method Case study Setiabudi and Tebet Districts,” South Jakarta Environmental Sciences 17. 685-692. 2013.

[6] Wielowariantowa koncepcja przedsięwzięcia: rekultywacja zbiornika odpadów niebezpiecznych i szkodliwych po zakładach Górka w Trzebini. PIG, SOCOTEC, PEGEOL, 2010.

[7] Zopp, C. and Lai, S., “Assessment of the Regional Landscape Plan of Sardinia (Italy): A participatory-action-research case study type,” Land Use Policy 27. 690-705. 2010. 